\title{
Wpływ odległości od konkurenta, dostawcy i odbiorcy na aktywność innowacyjną przedsiębiorstw przemysłu średnio niskiej techniki w Polsce
}

\section{The Impact of Spatial Proximity to Competitor, Supplier and Customer on Innovation Activity in Medium-Low Industry in Poland}

Streszczenie: Praca przedstawia wyniki badania, którego celem jest określenie wpływu odległości od konkurenta, dostawcy i odbiorcy na aktywność innowacyjną przedsiębiorstw reprezentujących przemysł średnioniskiej techniki w Polsce w latach 2008-2013. Zakres badania dotyczy innowacji na poziomie przedsiębiorstwa i uwzględnia dyfuzję do poziomu „nowość dla przedsiębiorstwa”. Działania innowacyjne uwzględnione w badaniu obejmują inwestycje, w tym nakłady na badania i rozwój (B + R), implementacje wyrobów i procesów technologicznych oraz współpracę innowacyjną. Badanie obejmuje 2301 przedsiębiorstw. W pracy założono, że bliskość geograficzna dostawców i odbiorców sprzyja pobudzaniu aktywności innowacyjnej, podczas gdy bliskość konkurentów sprawia, że skłonność przedsiębiorstw do podejmowania aktywności innowacyjnej maleje. Część metodyczna analiz wykorzystuje modelowanie probitowe, dzięki któremu można określić prawdopodobieństwo podjęcia danego działania innowacyjnego w funkcji odległości do danego partnera (konkurenta, dostawcy, odbiorcy). Analiza pokazuje, że wpływ odległości danego rodzaju partnera oddziałuje w różny sposób na częstotliwość podejmowania danego działania innowacyjnego. Najwięcej związków znaleziono dla odbiorców i dostawców krajowych. Współpraca z partnerami zagranicznymi sprawia, że badane przedsiębiorstwa częściej są skłonne ponosić nakłady na działalność badawczo-rozwojową oraz częściej współpracują z instytucjami reprezentującymi świat nauki.

\begin{abstract}
The aim of this study is to determine the impact of spatial proximity to customers, suppliers and competitors on innovation activity in medium-low technology manufacturing industries in Poland in the years 2008-2013. The scope of the survey relates to innovation at the company level and takes into account the diffusion to the "novelty to the company". Innovative activities are divided into the following groups: investments in R\&D and fixed assets not used so far such as buildings, premises and land; machinery and equipment, computer software; implementation of new products and processes; and innovative collaboration. The survey covers 2,301 industrial enterprises. It is assumed that innovation activity is facilitated by both local suppliers and customers, whereas it is impeded by local competitors. The methodological part of the study is based on probit modeling which enables to identify the probability of occurrence of innovation activity depending on geographical proximity of competitor, supplier and customer. The study shows that the impact of geographical proximity on innovation activity is diversified. The highest number of relationships relates to national suppliers and customers. The cooperation with foreign partners is positively correlated with R\&D expenditures and propensity to cooperation with universities.
\end{abstract}

Słowa kluczowe: aktywność innowacyjna; dostawca; konkurent; odbiorca; odległość Keywords: competitor; customer; innovation activity; proximity; supplier 
Otrzymano: 19 grudnia 2016

Received: 19 December 2016

Zaakceptowano: 14 lutego 2017

Accepted: 14 February 2017

Sugerowana cytacja / Suggested citation:

Dzikowski, P. (2017). Wpływ odległości od konkurenta, dostawcy i odbiorcy na aktywność innowacyjną przedsiębiorstw przemysłu średnio niskiej techniki w Polsce. Prace Komisji Geografii Przemysłu Polskiego Towarzystwa Geograficznego, 31(1), 24-37.

\section{WSTĘP}

Rosnąca dynamika i złożoność wymagań rynkowych sprawia, że tylko największe przedsiębiorstwa stać na samodzielne prowadzenie działalności innowacyjnej, ale i one coraz częściej stają się częścią złożonych struktur sieciowych obejmujących dostawców, odbiorców i konkurentów umiejscowionych zarówno w najbliższym otoczeniu przedsiębiorstwa (lokalnie, w regionie), jak i znajdujących się w jego dalszym otoczeniu (w kraju lub poza jego granicami) (Powell, Koput, Smith-Doerr, 1996). Zachodzące pomiędzy uczestnikami takich sieci interakcje prowadzą do wymiany wiedzy i informacji, a proces ten przybiera unikalne formy, specyficzne dla uczestników i otoczenia, w którym się odbywa (Edquist i inni, 2001; Wach, 2016). Funkcjonując w ramach sieci, przedsiębiorstwa realizują swoje cele lub cele sieci, przy jednoczesnym - możliwie minimalnym - nakładzie własnym zasobów. Wśród najważniejszych zalet sieci wyróżnia się: wykorzystanie dźwigni zasobów zależących od partnerów, większą szybkość działania, elastyczność i dostęp do innych zasobów, łatwiejszy dostęp do informacji, szybsze przenikanie wiedzy, mniejsze koszty działania, bliższe kontakty z klientami, większą innowacyjność (Cieślik, Michałek, Szczygielski, 2016; Stańczyk-Hugiet, Sus, 2012). Sieci istnieją jako określone przez specyficzne uwarunkowania struktury , które oznaczają współdziałanie, koordynację, komunikację, a czasami również wspólnotę celów (Czakon, 2012). Powiązania kreowane przez aktorów sieci istotnie wpływają na organizację przestrzeni, w której funkcjonują (Dzikowski, 2016; Majewska, Truskolaski, 2017). W pracach z zakresu geografii ekonomicznej zakłada się, że bliskość przestrzenna organizacji sprzyja procesom wzajemnego uczenia się, umożliwiając pracownikom przedsiębiorstw znajdujących się blisko siebie (lokalnie) częstsze spotkania, co zwiększa prawdopodobieństwo nawiązania bliższych relacji oraz szansę na szybsze zawiązanie nieformalnej współpracy, która przerodzi się w formalną współpracę reprezentowanych przez nich firm (Bell, 2005; Gilbert, McDougall, Audretsch, 2008; Gjelsvik, 2014). Czynniki te są konieczne do wypracowania odpowiedniego poziomu zaufania, który jest wymagany, aby nastąpiła wymiana wiedzy (Gertler, 2003; Mu, Peng, Love, 2008). Współcześnie opisany proces wypracowywania wzajemnego zaufania, z uwagi na szybko postępującą internacjonalizację działalności gospodarczej, dawno wyszedł poza ramy terytorialne (Bunnel, Coe, 2001; Kaczmarska-Krawczak, 2016). Stąd też maleje znaczenie posiadania osobistych kontaktów dla nawiązania współpracy innowacyjnej (Freel, 2003). Bezpośrednie interakcje mogą być pomocne w kluczowych momentach procesu innowacyjnego, ale w pozostałym czasie komunikacja oparta na elektronicznych środkach przekazu, takich jak poczta elektroniczna, komunikator czy telefon, jest wystarczająca (Gallaud, Torre, 2005). 
Celem pracy jest określenie wpływu odległości od konkurenta, dostawcy i odbiorcy na rodzaj podejmowanej działalności innowacyjnej przedsiębiorstw średnio niskiej techniki w Polsce. W artykule założono, że wzrost odległości od dostawcy i odbiorcy negatywnie wpływa na aktywność innowacyjną, podczas gdy duża odległość od konkurenta wpływa na nią pozytywnie.

Punktem wyjściowym pracy jest wprowadzenie teoretyczne, przedstawiające przestrzenne uwarunkowania funkcjonowania sieci przedsiębiorstw przemysłowych. W kolejnej części omówiona została metodyka badania. W części empirycznej zaprezentowano wyniki modelowania probitowego. W podsumowaniu przeprowadzono dyskusję nad uzyskanymi rezultatami, wskazano ograniczenia oraz możliwości pogłębienia zgromadzonej wiedzy.

\section{PRZESTRZENNE UWARUNKOWANIA FUNKCJONOWANIA SIECI}

Pod pojęciem sieci międzyorganizacyjnej ${ }^{1}$ będziemy rozumieć względnie trwałe zgrupowanie autonomicznych, wyspecjalizowanych firm, które uczestniczą w systemie kooperacji opartym na zasadach rynkowych, przy czym jest to układ przynajmniej trzech organizacji zorientowanych na realizację zbieżnych celów (Czakon, 2012). Tak zdefiniowana sieć może przyjmować zróżnicowane formy, rozmiary i charakter organizacyjny, determinowany stopniem złożoności i jakości powiązań. Sieci międzyorganizacyjne funkcjonują w różnych sektorach gospodarki, w tym w przemyśle średnio niskiej techniki.

Innowacja w tak rozumianym kontekście jest określana jako rezultat interakcji zachodzących w procesie nabywania wiedzy pomiędzy przedsiębiorstwem a pozostałymi uczestnikami rynku (Rogut, 2007), przy czym rezultat ten może obejmować wdrożenie nowego lub znacząco udoskonalonego produktu (wyrobu lub usługi) bądź procesu, nowej metody marketingowej lub nowej metody organizacyjnej w praktyce gospodarczej, organizacji miejsca pracy albo w stosunkach z otoczeniem (OECD, 2008).

Innowacje techniczne dotyczą zmian w technice i technologii. Obejmują one innowacje produktowe, procesowe i organizacyjne. Wyróżnia się trzy stopnie nowości innowacji: nowość na skalę światową, w skali kraju lub branży i nowość w skali danego przedsiębiorstwa (Janasz, Kozioł-Nadolna, 2011). Działalność innowacyjna wiąże się z ponoszeniem nakładów na: prace badawczo rozwojowe, technologie niematerialne, zakup zaawansowanych maszyn, urządzeń, sprzętu lub oprogramowania komputerowego, a także gruntów i budynków (w tym ulepszeń i napraw), szkolenia personelu i marketing nowych oraz ulepszonych produktów, pozostałe działania obejmujące prace projektowe, planowanie i testowanie nowych produktów i usług, procesy produkcyjne i metody dostarczania (Dwojacki, Hlousek, 2008). Szczególnym rodzajem sieci międzyorganizacyjnej jest sieć innowacyjna, której uczestnicy prowadzą działalność innowacyjną. Działalność sieci innowacyjnej obejmuje kreację, kombinację wymianę, transformację, absorpcję i eksploatację zasobów w powiązaniu z szeroko rozumianymi relacjami formalnymi i nieformalnymi (Ahuja, 2000). Charakterystyczną cechą sieci innowacyjnej są związki zachodzące pomiędzy jej podmiotami, należącymi do trzech grup: przedsiębiorstw, sektora nauki oraz administracji państwowej (Etzkowitz,

${ }^{1}$ Sieć międzyorganizacyjna określana jest w polskiej literaturze jako: sieć, organizacja sieciowa, sieć przedsiębiorstw, sieć gospodarcza, zaś w literaturze anglojęzycznej jako: network, business network, inter-firm network, inter-organizational network, czy network organization. 
Leydesdorff, 2000). Zachodzący przy tej okazji proces wymiany wiedzy i informacji prowadzi do powstania unikalnych relacji, które kształtują tempo i kierunek przepływu wiedzy (Storper, 1995). Powiązania dotyczą zarówno integracji pionowych, jak i poziomych. Interakcje wymagają bezpośredniego kontaktu, co prowadzi do ścisłego zbliżenia zaangażowanych partnerów (Świadek, Szopik-Depczyńska, 2011) i przyczynia się do pogłębienia współpracy (Saxenian, 1994). W erze globalnej gospodarki i związanej z nią rewolucji technologicznej, gdy informacja i jej przepływ nie znają granic, geografia nabiera coraz większego znaczenia (Audretsch, 1998). Jednak bliskość przestrzenna nie zawsze przyczynia się do intensyfikacji współpracy pomiędzy partnerami (Rees, Lorenz, Vincent-Lacrin, 2001), może jednak w określonych warunkach wspierać transfer wiedzy ukrytej (Bell, Zaheer, 2007). Istotnym elementem tego procesu jest baza wiedzy, specyficzna dla danego przemysłu, która determinuje rodzaj i charakter tworzonych związków (Malerba, 2004). Natomiast z perspektywy aktywności innowacyjnej duże znaczenie mają: miejsce zajmowane przez przedsiębiorstwo w sieci (Bell, 2005), rodzaj przemysłu, do którego należy firma, struktura sieci, którą współtworzy oraz rodzaj współdzielonych informacji (Zaheer, Bell, 2005).

\section{METODYKA BADANIA I CHARAKTERYSTYKA PRÓBY BADAWCZEJ}

Materiał, na podstawie którego przeprowadzone zostały obliczenia, pozyskano przy pomocy kwestionariusza ankietowego wysyłanego pocztą elektroniczną do przedsiębiorstw przemysłowych z terenu całej Polski. Badania mają charakter statyczny i dotyczą lat 2008-2013. Dane teleadresowe przedsiębiorstw pochodziły z publicznie dostępnych źródeł, takich jak: Teleadreson, Polskie Książki Telefoniczne i wybrane bazy sektorowe. Ze względu na ogólnopolski zakres badania dane były zbierane regionami i obejmowały przedsiębiorstwa przemysłowe o każdym poziomie techniki. Z uwagi na zróżnicowanie regionalne liczba przedsiębiorstw w poszczególnych regionach, do których zostały wysłane kwestionariusze ankietowe, była różna. Dane z każdego regionu zostały zagregowane do wspólnej bazy. Zgromadzono materiał od 7800 firm, przy czym poziom zwrotu ankiet wyniósł 15\%. Z tak zbudowanej bazy danych została wyselekcjonowana grupa przedsiębiorstw charakteryzująca się średnio niskim poziomem techniki, obejmująca dziedziny, w których nakłady na działalność B + R mieszczą się w zakresie 0,5-1\% wartości sprzedaży (Hatzichronoglou, 1997), zawierająca 2301 firm, tj. 29,5\% całej grupy, co odpowiada rzeczywistemu udziałowi przedsiębiorstw przemysłu średnio niskiej techniki w Polsce (Rocznik statystyczny przemysłu, 2014). Przyjęte w badaniu zmienne objaśniane (nakłady na $B+R$, inwestycje $w$ dotychczas niestosowane środki trwałe ogółem, w tym w budynki, lokale i grunty, maszyny i urządzenia techniczne oraz oprogramowanie komputerowe, implementacje nowych lub udoskonalonych wyrobów lub procesów technologicznych, w tym metod wytwarzania, systemów okołoprzemysłowych i systemów wspierających oraz współpracy innowacyjnej z dostawcami, konkurentami, jednostkami PAN, szkołami wyższymi, krajowymi i zagranicznymi jednostkami badawczo-rozwojowymi - JBR, odbiorcami i ogółem) oraz zmienne objaśniające (odległość od konkurenta, dostawcy i odbiorcy zdefiniowana z perspektywy lokalnej, regionalnej, krajowej i zagranicznej) miały charakter dychonomiczny, co sprawiło, że analizę przeprowadzono w oparciu o modelowanie probitowe (Aldrich, Nelson, 1984; Liao, 1994). 
Dla każdego modelu istotnego statystycznie wyznaczono prawdopodobieństwo $\mathrm{P}_{1}$ wystąpienia danej relacji dla badanej zmiennej (odległość od konkurenta, dostawcy i odbiorcy) oraz prawdopodobieństwo $\mathrm{P}_{2}$ jej wystąpienia dla pozostałych przypadków. Dla dodatniego znaku występującego przy parametrze $\mathrm{P}_{1}$ oznacza, że prawdopodobieństwo zajścia zdarzenia innowacyjnego jest wyższe dla badanej zmiennej niż w pozostałej zbiorowości. Każdorazowo dla modeli istotnych statystycznie podano asymptotyczny standardowy błąd estymatora parametru zmiennej niezależnej (BłSt).

Prezentowany zakres badania jest związany z innowacjami w firmach charakteryzujących się średnio niskim poziomem techniki. Innowacje są rozpatrywane na poziomie przedsiębiorstwa. Badanie uwzględnia dyfuzję typu „nowość w skali firmy”. Tab. 1 przedstawia strukturę badanych przedsiębiorstw ze względu na ich przynależność do podsekcji Polskiej Klasyfikacji Działalności (PKD). Wśród 2301 zbadanych firm mikroprzedsiębiorstwa to 33,07\%, małe to $36,94 \%$, średnie $-23,38 \%$, a duże $-6,61 \%$. Kapitał krajowy jest reprezentowany przez 86,09\% jednostek, podczas gdy udział przedsiębiorstw z kapitałem zagranicznym wynosi 6,95\%.

Tab. 1. Struktura badanych przedsiębiorstw wg klasyfikacji PKD

\begin{tabular}{|l|c|}
\hline \multicolumn{1}{|c|}{ Nazwa branży } & Udział (w \%) \\
\hline Produkcja i naprawa statków i łodzi & $83(3,61 \%)$ \\
\hline Wytwarzanie koksu, produktów rafinacji ropy naftowej i paliw jądrowych & $32(1,39 \%)$ \\
\hline Produkcja wyrobów gumowych z tworzyw sztucznych & $578(25,12 \%)$ \\
\hline Produkcja wyrobów z surowców niemetalicznych pozostałych & $562(24,42 \%)$ \\
\hline Produkcja metali & $187(8,13 \%)$ \\
\hline Produkcja metalowych wyrobów gotowych, z wyjątkiem maszyn i urządzeń & $859(37,33 \%)$ \\
\hline Razem & $2301(100 \%)$ \\
\hline
\end{tabular}

Źródło:·opracowanie własne

Ryc. 1 przedstawia strukturę lokalizacji odbiorcy, dostawcy i konkurenta. Najmniejszy udział w strukturze zajmują partnerzy zagraniczni - 7,46\%. Udział pozostałych

Ryc. 1. Struktura lokalizacji odbiorcy, dostawcy i konkurenta

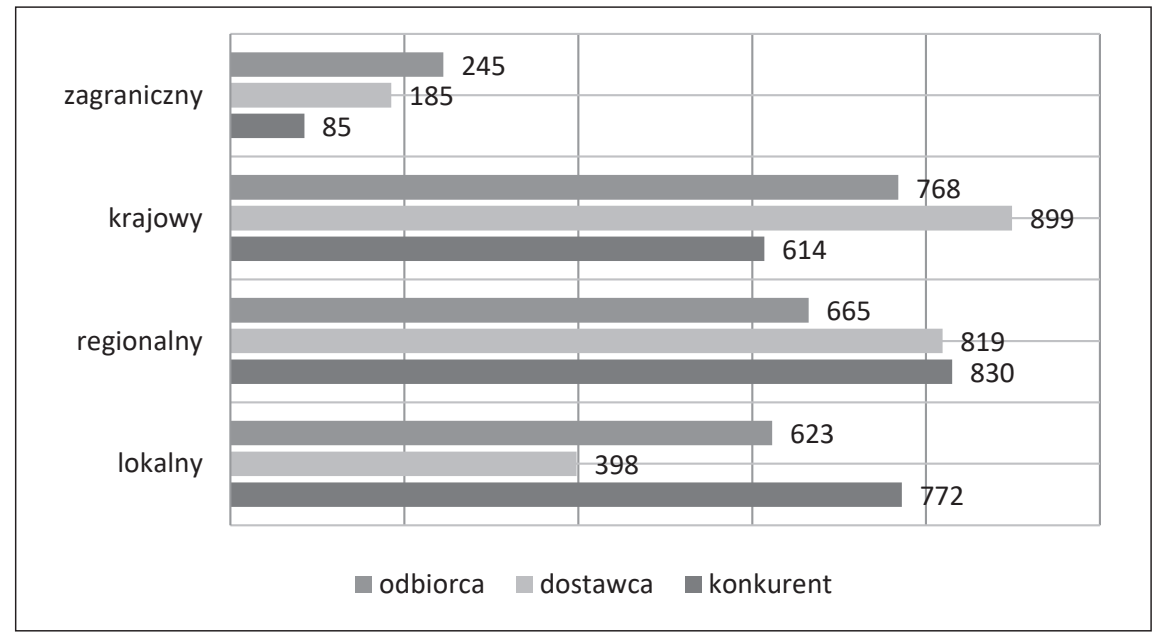

Źródło: opracowanie własne 
rodzajów partnerów jest zbliżony i wynosi dla podmiotów krajowych 33,04\%, a dla partnerów funkcjonujących w tym samym regionie co badane przedsiębiorstwo 33,52\%. Natomiast udział partnerów lokalnych wynosi 25,97\%. Udział odbiorców, dostawców i konkurentów w poszczególnych lokalizacjach jest bardzo zróżnicowany. Wśród partnerów zagranicznych dominują odbiorcy - 47,57\%. Wśród partnerów krajowych dominują dostawcy - 39,41\%. W regionie liczba konkurentów - 35,87\% nieznacznie przekracza liczbę dostawców - 35,39\%. Natomiast na poziomie lokalnym dominują konkurenci $-43,06 \%$.

Tab. 2 przedstawia strukturę podejmowanych działań innowacyjnych. Najczęściej podejmowanymi działaniami innowacyjnymi są: inwestycje w dotychczas niestosowane środki trwałe ogółem (12,59\%), implementacja nowych lub istotnie ulepszonych procesów technologicznych ogółem $(11,88 \%)$ oraz inwestycje w maszyny i urządzenia $(11,27 \%)$. Najrzadziej podejmowanymi działaniami innowacyjnymi są: współpraca innowacyjna z instytucjami reprezentującymi naukę, w tym z jednostkami Polskiej Akademii Nauk (0,25\%), współpraca z zagranicznymi jednostkami badawczo-rozwojowymi $(0,35 \%)$ oraz współpraca ze szkołami wyższymi $(0,67 \%)$.

Tab. 2. Struktura podejmowanych działań innowacyjnych

\begin{tabular}{|l|c|}
\hline \multicolumn{1}{|c|}{ Działanie innowacyjne } & $\begin{array}{c}\text { Udział w aktywności } \\
\text { innowacyjnej (w \%) }\end{array}$ \\
\hline Inwestycje w dotychczas niestosowane środki trwałe ogółem & $12,59 \%$ \\
\hline Implementacja nowych lub istotnie ulepszonych procesów technologicznych ogółem & $11,88 \%$ \\
\hline Inwestycje w maszyny i urządzenia & $11,27 \%$ \\
\hline Wprowadzanie nowych lub istotnie ulepszonych wyrobów & $9,60 \%$ \\
\hline Inwestycje w oprogramowanie komputerowe & $9,53 \%$ \\
\hline Implementacja metod wytwarzania & $7,80 \%$ \\
\hline Współpraca innowacyjna ogółem & $6,92 \%$ \\
\hline Nakłady na B + R & $5,95 \%$ \\
\hline Implementacja systemów okołoprzemysłowych & $5,25 \%$ \\
\hline Współpraca innowacyjna z dostawcami & $4,29 \%$ \\
\hline Inwestycje w budynki, lokale i grunty & $4,25 \%$ \\
\hline Implementacja systemów wspierających (np. programów informatycznych & $3,66 \%$ \\
\hline w księgowości) & $3,52 \%$ \\
\hline Współpraca innowacyjna z odbiorcami & $1,38 \%$ \\
\hline Współpraca innowacyjna z krajowymi JBR & $0,84 \%$ \\
\hline Współpraca innowacyjna z konkurentami & $0,67 \%$ \\
\hline Współpraca innowacyjna ze szkołami wyższymi & $0,35 \%$ \\
\hline Współpraca innowacyjna z zagranicznymi JBR & $0,25 \%$ \\
\hline Współpraca z jednostkami PAN & \\
\hline Źt & \\
\hline
\end{tabular}

Źródło: opracowanie własne

\section{WPŁYW ODLEGŁOŚCI OD KONKURENTA, DOSTAWCY I ODBIORCY NA AKTYWNOŚĆ INNOWACYJNĄ}

Tab. 3 zawiera zestawienie istotnych statystycznie modeli, w których parametrem jest „odległość od konkurenta”. Ujemny znak wyznaczonego parametru dla wszystkich modeli dotyczących konkurenta lokalnego i regionalnego oznacza, że prawdopodobieństwo 
podjęcia aktywności innowacyjnej jest mniejsze niż jej wystąpienia dla pozostałych analizowanych odległości. Analizując procentową różnicę wartości prawdopodobieństwa dla każdego z wyznaczonych modeli, ustalamy siłę wpływu danego typu konkurenta na wybrany rodzaj działalności innowacyjnej.

Największe spadki wielkości prawdopodobieństw dotyczą działań o najmniejszej wartości bezwzględnej prawdopodobieństw, w tym współpracy innowacyjnej z zagranicznymi jednostkami badawczo-rozwojowymi $(0,01)$, dla której spadek wynosi 200\%, oraz współpracy z krajowymi JBR $(0,05)$ i współpracy z jednostkami Polskiej Akademii Nauk $(0,01)$, dla których spadek wynosi po $100 \%$.

Obecność lokalnego konkurenta najmniej negatywnie wpływa na skłonność przedsiębiorstw do wprowadzania nowych lub ulepszonych wyrobów $(0,56)$ - spadek o 7\%, do inwestycji w dotychczas niestosowane środki trwałe $(0,71)$ - spadek o 12,7\%, w tym inwestycji w oprogramowanie komputerowe $(0,53)$ - spadek o $15 \%$.

Liczba zależności istotnych statystycznie w przypadku konkurenta regionalnego jest dużo niższa niż w przypadku konkurenta lokalnego. Obecność konkurenta w regionie sprawia, że przedsiębiorstwa rzadziej - spadek o 66,7\% - współpracują innowacyjnie ze szkołami wyższymi $(0,03)$.

Jeżeli główny lub najbliższy konkurent jest zlokalizowany w kraju, wtedy wzrasta znacznie aktywność innowacyjna badanych przedsiębiorstw. Obecność konkurencji krajowej najbardziej wzmaga współpracę innowacyjną ze szkołami wyższymi $(0,06)$ oraz z zagranicznymi JBR $(0,04)$ - wzrost o 50\% - oraz współpracę z krajowymi JBR $(0,12)$ - wzrost o $41,7 \%$. Najmniejszy wpływ dotyczy inwestycji w dotychczas niestosowane środki trwałe $(0,71)$ - wzrost o 8,5\%, w tym inwestycji w oprogramowanie komputerowe $(0,53)$ - wzrost o 6,56\%, oraz implementacji nowych lub istotnie ulepszonych procesów technologicznych ogółem $(0,65)$ - wzrost o 8,97\%.

Główny lub najbliższy konkurent ulokowany za granicą przyczynia się do współpracy innowacyjnej z jednostkami PAN $(0,05)$ - wzrost o 80\%, współpracy innowacyjnej z zagranicznymi JBR $(0,08)$ - wzrost o 75\%, oraz współpracy ze szkołami wyższymi $(0,14)$ - wzrost o $71,4 \%$.

Tab. 3. Modele probitowe opisujące aktywność innowacyjną w funkcji „odległości od konkurenta”

\begin{tabular}{|c|c|c|c|c|c|c|c|c|c|c|c|c|}
\hline \multirow{3}{*}{ Rodzaj działalności innowacyjnej } & \multicolumn{12}{|c|}{ Odległość od konkurenta } \\
\hline & \multicolumn{3}{|c|}{$\begin{array}{l}\text { Konkurent } \\
\text { lokalny }\end{array}$} & \multicolumn{3}{|c|}{$\begin{array}{l}\text { Konkurent } \\
\text { w regionie }\end{array}$} & \multicolumn{3}{|c|}{$\begin{array}{l}\text { Konkurent } \\
\text { w kraju }\end{array}$} & \multicolumn{3}{|c|}{$\begin{array}{l}\text { Konkurent za } \\
\text { granicą }\end{array}$} \\
\hline & BłS & P1 & $\mathrm{P} 2$ & BłS & P1 & $\mathrm{P} 2$ & $\mathrm{BłS}$ & P1 & $\mathrm{P} 2$ & BłS & P1 & $\mathrm{P} 2$ \\
\hline \multirow{2}{*}{ Nakłady na działalność B + R } & \multicolumn{3}{|c|}{-.27} & \multicolumn{3}{|c|}{-.17} & \multicolumn{3}{|c|}{.39} & \multicolumn{3}{|c|}{.42} \\
\hline & .06 & .30 & .40 & .06 & .32 & .39 & .06 & .47 & .32 & .14 & .52 & .36 \\
\hline \multirow{2}{*}{$\begin{array}{l}\text { Inwestycje w dotychczas } \\
\text { niestosowane środki trwałe }\end{array}$} & \multicolumn{3}{|c|}{-.32} & \multirow{2}{*}{\multicolumn{3}{|c|}{--}} & \multicolumn{3}{|c|}{.23} & \multirow{2}{*}{\multicolumn{3}{|c|}{-- }} \\
\hline & .06 & .71 & .80 & & & & .07 & .82 & .75 & & & \\
\hline \multirow{2}{*}{$\begin{array}{l}\text { Inwestycje w budynki, lokale } \\
\text { i grunty związane z wprowadzeniem } \\
\text { w przyszłości nowych wyrobów lub } \\
\text { procesów }\end{array}$} & \multicolumn{3}{|c|}{-.19} & \multirow{2}{*}{\multicolumn{3}{|c|}{--}} & \multirow{2}{*}{\multicolumn{3}{|c|}{--}} & \multicolumn{3}{|c|}{.43} \\
\hline & .06 & .22 & .28 & & & & & & & .14 & .41 & .25 \\
\hline \multirow{2}{*}{$\begin{array}{l}\text { Inwestycje w maszyny i urządzenia } \\
\text { techniczne, środki transportowe }\end{array}$} & \multicolumn{3}{|c|}{-.26} & \multirow{2}{*}{\multicolumn{3}{|c|}{-- }} & \multicolumn{3}{|c|}{.26} & \multirow{2}{*}{\multicolumn{3}{|c|}{--}} \\
\hline & .06 & .62 & .72 & & & & .06 & .75 & .67 & & & \\
\hline \multirow{2}{*}{$\begin{array}{l}\text { Inwestycje w oprogramowanie } \\
\text { komputerowe }\end{array}$} & \multicolumn{3}{|c|}{-.19} & \multirow{2}{*}{\multicolumn{3}{|c|}{-- }} & \multicolumn{3}{|c|}{.12} & \multicolumn{3}{|c|}{.65} \\
\hline & .06 & .53 & .61 & & & & .06 & .61 & .57 & .15 & .80 & .57 \\
\hline
\end{tabular}




\begin{tabular}{|c|c|c|c|c|c|c|c|c|c|c|c|c|}
\hline \multirow{2}{*}{$\begin{array}{l}\text { Wprowadzanie nowych lub istotnie } \\
\text { ulepszonych wyrobów }\end{array}$} & \multicolumn{3}{|c|}{-.12} & & \multirow{2}{*}{\multicolumn{2}{|c|}{-- }} & \multicolumn{3}{|c|}{.15} & \multirow{2}{*}{\multicolumn{3}{|c|}{--}} \\
\hline & .06 & .56 & .60 & & & & .06 & .63 & .57 & & & \\
\hline \multirow{2}{*}{$\begin{array}{l}\text { Implementacja nowych lub } \\
\text { istotnie ulepszonych procesów } \\
\text { technologicznych ogółem }\end{array}$} & \multicolumn{3}{|c|}{-.34} & \multirow{2}{*}{\multicolumn{3}{|c|}{--}} & \multicolumn{3}{|c|}{.22} & \multicolumn{3}{|c|}{.56} \\
\hline & .06 & .65 & .77 & & & & .06 & .78 & .71 & .17 & .88 & .72 \\
\hline \multirow{2}{*}{ Implementacja metod wytwarzania } & \multicolumn{3}{|c|}{-.18} & \multirow{2}{*}{\multicolumn{3}{|c|}{--}} & \multicolumn{3}{|c|}{.18} & \multirow{2}{*}{\multicolumn{3}{|c|}{-- }} \\
\hline & .06 & .43 & .50 & & & & .06 & .53 & .46 & & & \\
\hline \multirow{2}{*}{$\begin{array}{l}\text { Implementacja systemów } \\
\text { okołoprzemysłowych }\end{array}$} & \multicolumn{3}{|c|}{-.37} & \multirow{2}{*}{\multicolumn{3}{|c|}{--}} & \multicolumn{3}{|c|}{.19} & \multicolumn{3}{|c|}{.33} \\
\hline & .06 & .23 & .36 & & & & .06 & .37 & .30 & .14 & .44 & .32 \\
\hline \multirow{2}{*}{$\begin{array}{l}\text { Implementacja systemów } \\
\text { wspierających (np. programów } \\
\text { informatycznych w księgowości) }\end{array}$} & \multicolumn{3}{|c|}{-.29} & \multirow{2}{*}{\multicolumn{3}{|c|}{--}} & \multirow{2}{*}{\multicolumn{3}{|c|}{-- }} & \multicolumn{3}{|c|}{.36} \\
\hline & .06 & .17 & .25 & & & & & & & .14 & .34 & .22 \\
\hline \multirow{2}{*}{$\begin{array}{l}\text { Współpraca innowacyjna } \\
\text { z konkurentami }\end{array}$} & \multicolumn{3}{|c|}{-.19} & \multirow{2}{*}{\multicolumn{3}{|c|}{--}} & \multirow{2}{*}{\multicolumn{3}{|c|}{--}} & \multirow{2}{*}{\multicolumn{3}{|c|}{-- }} \\
\hline & .10 & .04 & .06 & & & & & & & & & \\
\hline \multirow{2}{*}{$\begin{array}{l}\text { Współpraca innowacyjna } \\
\text { z jednostkami PAN }\end{array}$} & & -.42 & & & & & & & & & .51 & \\
\hline & .18 & .01 & .02 & & -- & & & -- & & .24 & .05 & .01 \\
\hline Współpraca innowacyjna ze szkołami & & 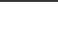 & & & -.26 & & & .26 & & & .68 & \\
\hline wyższymi & & -- & & .11 & .03 & .05 & .10 & .06 & .03 & .17 & .14 & .04 \\
\hline Współpraca innowacyjna z krajowymi & & -.39 & & & & & & .29 & & & .44 & \\
\hline JBR & .09 & .05 & .10 & & -- & & .08 & .12 & .07 & .16 & .17 & .08 \\
\hline Współpraca innowacyjna & & -.51 & & & & & & .33 & & & .67 & \\
\hline z zagranicznymi JBR & .16 & .01 & .03 & & -- & & .12 & .04 & .02 & .20 & .08 & .02 \\
\hline & & -.15 & & & - & & & .17 & & & -- & \\
\hline Wspołpraca innowacyj1 & .06 & .19 & .23 & & -- & & .06 & .25 & .20 & & -- & \\
\hline W & & -.16 & & & -.13 & & & .23 & & & .35 & \\
\hline Wspołpraca innowacyjna ogołem & .06 & .40 & .46 & .06 & .41 & .46 & .06 & .51 & .42 & .14 & .57 & .44 \\
\hline
\end{tabular}

Źródło: opracowanie własne

Tab. 4 zawiera modele opisujące aktywność innowacyjną w funkcji „odległości od dostawcy”. Obecność lokalnych dostawców osłabia aktywność innowacyjną w wielu badanych obszarach. Obecność lokalnego dostawcy najbardziej negatywnie wpływa na współpracę innowacyjną z krajowymi JBR $(0,05)$ - spadek o 80\%, implementację systemów okołoprzemysłowych $(0,23)$ - spadek o 47,8\%, oraz nakłady na działalność B + R $(0,29)$ - spadek o 31\%. Najmniejszy negatywny wpływ dostawców lokalnych odnosi się do inwestycji w dotychczas niestosowane środki trwałe $(0,7)$ - spadek o 12,9\%, w tym inwestycji w maszyny i urządzenia techniczne $(0,62)$ - spadek o $14,5 \%$, oraz inwestycji w oprogramowanie komputerowe $(0,52)$ - spadek o $13,5 \%$.

Wpływ dostawcy pochodzącego z regionu, w którym funkcjonuje badane przedsiębiorstwo, jest słabszy niż w przypadku wpływu dostawcy lokalnego, ale również negatywny. Dostawcy regionalni osłabiają skłonność przedsiębiorstw do podejmowania współpracy innowacyjnej z zagranicznymi JBR $(0,01)$ - spadek o 200\%, ze szkołami wyższymi $(0,03)$ - spadek o 66,7\%, oraz do implementacji systemów wspierających $(0,19)$ - spadek o $31,6 \%$.

Współpraca z dostawcą krajowym stymuluje aktywność innowacyjną niemal we wszystkich działaniach, ale najbardziej we współpracy innowacyjnej z zagranicznymi JBR $(0,03)$ - wzrost o 33,3\%, krajowymi JBR $(0,1)$ - wzrost o $30 \%$, oraz w obszarze nakładów na działalność B + R $(0,4)$ - wzrost o $15 \%$. 
Najmniejszy wpływ dotyczy inwestycji w maszyny i urządzenia techniczne $(0,72)$ wzrost o 6,9\%, implementacji nowych lub istotnie ulepszonych procesów technologicznych ogółem $(0,76)$ - wzrost o $6,6 \%$, oraz wprowadzania nowych lub istotnie ulepszonych wyrobów $(0,62)$ - wzrost o 8,1\%.

Główny lub najbliższy dostawca ulokowany za granicą powoduje, że przedsiębiorstwo częściej współpracuje innowacyjnie ze szkołami wyższymi $(0,11)$ - wzrost o 72,7\%, oraz z zagranicznymi JBR $(0,07)$ - wzrost o 71,4\%, także częściej implementuje systemy wspierające $(0,34)$ - wzrost o $38,2 \%$, i systemy okołoprzemysłowe - wzrost o $32,6 \%$.

Tab. 4. Modele probitowe opisujące aktywność innowacyjną w funkcji „odległości od dostawcy”

\begin{tabular}{|c|c|c|c|c|c|c|c|c|c|c|c|c|}
\hline \multirow{3}{*}{ Rodzaj działalności innowacyjnej } & \multicolumn{12}{|c|}{ Odległość od dostawcy } \\
\hline & \multicolumn{3}{|c|}{$\begin{array}{c}\text { Dostawca } \\
\text { lokalny }\end{array}$} & \multicolumn{3}{|c|}{$\begin{array}{l}\text { Dostawca } \\
\text { w regionie }\end{array}$} & \multicolumn{3}{|c|}{$\begin{array}{c}\text { Dostawca } \\
\text { w kraju }\end{array}$} & \multicolumn{3}{|c|}{$\begin{array}{l}\text { Dostawca za } \\
\text { granicą }\end{array}$} \\
\hline & BłS & P1 & $\mathrm{P} 2$ & $\mathrm{BłS}$ & $\mathrm{P} 1$ & $\mathrm{P} 2$ & $\mathrm{BłS}$ & $\mathrm{P} 1$ & $\mathrm{P} 2$ & $\mathrm{BłS}$ & $\mathrm{P} 1$ & $\mathrm{P} 2$ \\
\hline \multirow{2}{*}{ Nakłady na działalność B + R } & \multicolumn{3}{|c|}{-.25} & \multicolumn{3}{|c|}{-.15} & \multicolumn{3}{|c|}{.17} & \multicolumn{3}{|c|}{.42} \\
\hline & .07 & .29 & .38 & .06 & .33 & .38 & .06 & .34 & .40 & .09 & .51 & .35 \\
\hline \multirow{2}{*}{$\begin{array}{l}\text { Inwestycje w dotychczas niestosowane } \\
\text { środki trwałe }\end{array}$} & \multicolumn{3}{|c|}{-.29} & \multirow{2}{*}{\multicolumn{3}{|c|}{--}} & \multirow{2}{*}{\multicolumn{3}{|c|}{--}} & \multicolumn{3}{|c|}{.21} \\
\hline & .07 & .70 & .79 & & & & & & & .11 & .83 & .77 \\
\hline \multirow{2}{*}{$\begin{array}{l}\text { Inwestycje w budynki, lokale } \\
\text { i grunty związane z wprowadzeniem } \\
\text { w przyszłości nowych wyrobów lub } \\
\text { procesów }\end{array}$} & \multirow{2}{*}{\multicolumn{3}{|c|}{--}} & \multicolumn{3}{|c|}{-.13} & \multirow{2}{*}{\multicolumn{3}{|c|}{--}} & & .28 & \\
\hline & & & & .06 & .23 & .28 & & & & .09 & .35 & .25 \\
\hline \multirow{2}{*}{$\begin{array}{l}\text { Inwestycje w maszyny i urządzenia } \\
\text { techniczne, środki transportowe }\end{array}$} & \multicolumn{3}{|c|}{-.25} & \multirow{2}{*}{\multicolumn{3}{|c|}{--}} & \multicolumn{3}{|c|}{.12} & \multicolumn{3}{|c|}{.24} \\
\hline & .07 & 62 & .71 & & & & .06 & .72 & .67 & .10 & .76 & .68 \\
\hline \multirow{2}{*}{$\begin{array}{l}\text { Inwestycje w oprogramowanie } \\
\text { komputerowe }\end{array}$} & \multicolumn{3}{|c|}{-.18} & & -.21 & & & .17 & & & .45 & \\
\hline & .07 & .52 & .59 & .05 & .61 & .53 & .05 & .62 & .55 & .10 & .73 & .56 \\
\hline Wprowadzanie nowych lub istotnie & & - & & & - & & & .14 & & & & \\
\hline ulepszonych wyrobów & & -- & & & -- & & .05 & .62 & .57 & & -- & \\
\hline Implementacja nowych lub & & -.38 & & & & & & .17 & & & .34 & \\
\hline $\begin{array}{l}\text { istotnie ulepszonych procesow } \\
\text { technologicznych ogółem }\end{array}$ & .07 & .62 & .75 & & -- & & .06 & .76 & .71 & .11 & .82 & .72 \\
\hline & & -.21 & & & & & & & & & .21 & \\
\hline implementacja metoa wyıwarzania & .07 & .41 & .49 & & -- & & & -- & & .09 & .56 & .47 \\
\hline Implementacja systemów & & -.34 & & & & & & & & & .41 & \\
\hline okołoprzemysłowych & .08 & .23 & .34 & & -- & & & -- & & .09 & .46 & .31 \\
\hline Implementacja systemów & & & & & -.20 & & & .14 & & & .39 & \\
\hline $\begin{array}{l}\text { wspierających (np. programów } \\
\text { informatycznych w księgowości) }\end{array}$ & & -- & & .06 & .19 & .25 & .06 & .25 & .21 & .10 & .34 & .21 \\
\hline Współpraca innowacyjna ze szkołami & & - & & & -.25 & & & 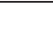 & & & .60 & \\
\hline wyższymi & & -- & & .10 & .03 & .05 & & -- & & .13 & .11 & .03 \\
\hline Współpraca innowacyjna z krajowymi & & -.29 & & & & & & .17 & & & & \\
\hline JBR & .11 & .05 & .09 & & -- & & .08 & .10 & .07 & & -- & \\
\hline Współpraca innowacyjna & & & & & -.55 & & & .27 & & & .63 & \\
\hline z zagranicznymi JBR & & -- & & .16 & .01 & .03 & .12 & .03 & .02 & .15 & .07 & .02 \\
\hline $\mathrm{W}$ & & -.21 & & & $-\theta_{-1}$ & & & .11 & & & .29 & \\
\hline VVsporpracd innowacyjnd ogorem & .07 & .38 & .46 & & & & .05 & .47 & .43 & .09 & .54 & .43 \\
\hline
\end{tabular}

Źródło: opracowanie własne 
Tab. 5 przedstawia modele opisujące aktywność innowacyjną w funkcji „odległości od odbiorcy”. Współpraca z odbiorcami lokalnymi obniża aktywność innowacyjną zarówno w obszarze inwestycji i implementacji, jak i współpracy, przy czym wpływ ten jest bardzo duży, gdyż dotyczy 16 z 18 badanych działalności innowacyjnych.

Największy negatywny wpływ lokalnych odbiorców jest widoczny w obszarze współpracy innowacyjnej z zagranicznymi JBR (0,01) - spadek o 200\%, współpracy innowacyjnej z krajowymi JBR $(0,04)$ oraz współpracy innowacyjnej z konkurentami $(0,03)$ - spadek o $100 \%$.

Najmniejszy wpływ lokalnych odbiorców uwidacznia się w zakresie inwestycji w dotychczas niestosowane środki trwałe $(0,7)$ - spadek o $14,3 \%$, w tym inwestycji w maszyny i urządzenia techniczne $(0,63)$ - spadek o $12,7 \%$, oraz implementacji nowych lub istotnie ulepszonych procesów technologicznych ogółem $(0,65)$ - spadek o 16,9\%, i współpracy innowacyjnej z dostawcami $(0,23)$ - spadek o 17,3\%.

Wpływ odbiorcy w regionie jest niejednoznaczny i słabszy niż w przypadku wpływu odbiorcy lokalnego. Odbiorca regionalny osłabia skłonność przedsiębiorstwa do podejmowania współpracy innowacyjnej z zagranicznymi JBR $(0,01)$ - spadek o 200\%, oraz inwestycji w budynki, lokale i grunty związane z wprowadzaniem w przyszłości nowych wyrobów lub procesów $(0,23)$ - spadek o 17,4\%, ale sprzyja podejmowaniu współpracy innowacyjnej z konkurentami $(0,07)$ - wzrost o 42,9\%.

Współpraca z odbiorcą krajowym sprzyja aktywności innowacyjnej, w tym najbardziej współpracy innowacyjnej z zagranicznymi JBR $(0,04)$ - wzrost o 75\%, krajowymi JBR $(0,12)$ - wzrost o $41,7 \%$, i szkołami wyższymi $(0,06)$ - wzrost o $50 \%$.

Najmniejszy wpływ dotyczy inwestycji w dotychczas niestosowane środki trwałe $(0,81)$ - wzrost o 7,4\%, i implementacji nowych lub istotnie ulepszonych procesów technologicznych ogółem $(0,77)$ - wzrost o 7,8\%.

Główny lub najbliższy odbiorca ulokowany za granicą sprzyja podejmowaniu współpracy innowacyjnej z zagranicznymi JBR $(0,06)$ - wzrost o 66,7\%, współpracy innowacyjnej ze szkołami wyższymi $(0,07)$ - wzrost o 42,9\%, oraz inwestycjom w budynki, lokale i grunty związane z wprowadzaniem w przyszłości nowych wyrobów lub procesów $(0,4)$ - wzrost o $40 \%$.

Tab. 5. Modele probitowe opisujące aktywność innowacyjną w funkcji „odległości od odbiorcy”

\begin{tabular}{|c|c|c|c|c|c|c|c|c|c|c|c|c|}
\hline \multirow{3}{*}{ Rodzaj działalności innowacyjnej } & \multicolumn{12}{|c|}{ Odległość od odbiorcy } \\
\hline & \multicolumn{3}{|c|}{$\begin{array}{l}\text { Odbiorca } \\
\text { lokalny }\end{array}$} & \multicolumn{3}{|c|}{$\begin{array}{l}\text { Odbiorca } \\
\text { w regionie }\end{array}$} & \multicolumn{3}{|c|}{$\begin{array}{l}\text { Odbiorca } \\
\text { w kraju }\end{array}$} & \multicolumn{3}{|c|}{$\begin{array}{l}\text { Odbiorca za } \\
\text { granicą }\end{array}$} \\
\hline & $\mathrm{B} ł \mathrm{~S}$ & P1 & $\mathrm{P} 2$ & BłS & $\mathrm{P} 1$ & $\mathrm{P} 2$ & BłS & $\mathrm{P} 1$ & P2 & BłS & $\mathrm{P} 1$ & $\mathrm{P} 2$ \\
\hline \multirow{2}{*}{ Nakłady na działalność B + R } & \multicolumn{3}{|c|}{-.33} & \multirow{2}{*}{\multicolumn{3}{|c|}{--}} & \multicolumn{3}{|c|}{.28} & \multicolumn{3}{|c|}{.28} \\
\hline & .06 & .28 & .40 & & & & .06 & .43 & .33 & .0 .08 & .46 & .35 \\
\hline \multirow{2}{*}{$\begin{array}{l}\text { Inwestycje w dotychczas niestosowane } \\
\text { środki trwałe }\end{array}$} & \multicolumn{3}{|c|}{-.30} & \multirow{2}{*}{\multicolumn{3}{|c|}{--}} & \multicolumn{3}{|c|}{.17} & \multicolumn{3}{|c|}{.19} \\
\hline & .06 & .70 & .80 & & & & .06 & .81 & .75 & .09 & .82 & .77 \\
\hline \multirow{2}{*}{$\begin{array}{l}\text { Inwestycje w budynki, lokale } \\
\text { i grunty związane z wprowadzeniem } \\
\text { w przyszłości nowych wyrobów lub } \\
\text { procesów }\end{array}$} & \multicolumn{3}{|c|}{-.27} & \multicolumn{3}{|c|}{-.13} & & & & \multicolumn{3}{|c|}{.45} \\
\hline & .07 & .28 & .20 & .06 & .23 & .27 & & -- & & .08 & .40 & .24 \\
\hline \multirow{2}{*}{$\begin{array}{l}\text { Inwestycje w maszyny i urządzenia } \\
\text { techniczne, środki transportowe }\end{array}$} & \multicolumn{3}{|c|}{-.24} & \multirow{2}{*}{\multicolumn{3}{|c|}{--}} & & .17 & & \multirow{2}{*}{\multicolumn{3}{|c|}{-- }} \\
\hline & .06 & .63 & .71 & & & & .06 & .73 & .67 & & & \\
\hline
\end{tabular}




\begin{tabular}{|c|c|c|c|c|c|c|c|c|c|c|c|c|}
\hline \multirow{2}{*}{$\begin{array}{l}\text { Inwestycje w oprogramowanie } \\
\text { komputerowe }\end{array}$} & \multicolumn{3}{|c|}{-.26} & \multirow{2}{*}{\multicolumn{3}{|c|}{--}} & \multicolumn{3}{|c|}{.15} & \multicolumn{3}{|c|}{.37} \\
\hline & .06 & .50 & .61 & & & & .06 & .62 & .56 & .08 & .70 & .56 \\
\hline \multirow{2}{*}{$\begin{array}{l}\text { Wprowadzanie nowych lub istotnie } \\
\text { ulepszonych wyrobów }\end{array}$} & \multirow{2}{*}{\multicolumn{3}{|c|}{--}} & \multirow{2}{*}{\multicolumn{3}{|c|}{--}} & \multirow{2}{*}{\multicolumn{3}{|c|}{--}} & \multicolumn{3}{|c|}{.18} \\
\hline & & & & & & & & & & .08 & .65 & .58 \\
\hline \multirow{2}{*}{\begin{tabular}{|l|} 
Implementacja nowych lub \\
istotnie ulepszonych procesów \\
technologicznych ogółem \\
\end{tabular}} & \multicolumn{3}{|c|}{-.30} & \multirow{2}{*}{\multicolumn{3}{|c|}{-- }} & \multicolumn{3}{|c|}{.19} & \multicolumn{3}{|c|}{.25} \\
\hline & .06 & .65 & .76 & & & & .06 & .77 & .71 & .09 & .80 & .72 \\
\hline \multirow{2}{*}{ Implementacja metod wytwarzania } & \multicolumn{3}{|c|}{-.20} & \multirow{2}{*}{\multicolumn{3}{|c|}{--}} & \multicolumn{3}{|c|}{.15} & \multicolumn{3}{|c|}{.32} \\
\hline & .06 & .42 & .50 & & & & .06 & .52 & .46 & .08 & .59 & .46 \\
\hline \multirow{2}{*}{\begin{tabular}{|l|}
$\begin{array}{l}\text { Implementacja systemów } \\
\text { okołoprzemysłowych }\end{array}$ \\
\end{tabular}} & \multicolumn{3}{|c|}{-.30} & \multirow{2}{*}{\multicolumn{3}{|c|}{--}} & \multicolumn{3}{|c|}{.14} & \multicolumn{3}{|c|}{.26} \\
\hline & .06 & .25 & .35 & & & & .06 & .36 & .30 & .08 & .41 & .31 \\
\hline \multirow{2}{*}{$\begin{array}{l}\text { Implementacja systemów } \\
\text { wspierających (np. programów } \\
\text { informatycznych w księgowości) }\end{array}$} & \multicolumn{3}{|c|}{-.16} & \multirow{2}{*}{\multicolumn{3}{|c|}{--}} & \multirow{2}{*}{\multicolumn{3}{|c|}{--}} & \multirow{2}{*}{\multicolumn{3}{|c|}{--}} \\
\hline & .07 & .19 & .24 & & & & & & & & & \\
\hline Współpraca innowacyjna & & -.14 & & & & & & . & & & .24 & \\
\hline z dostawcami & .06 & .23 & .27 & & -- & & & -- & & .08 & .34 & .25 \\
\hline Współpraca innowacyjna & & -.29 & & & .26 & & & & & & & \\
\hline z konkurentami & .10 & .03 & .06 & .09 & .07 & .04 & & -- & & & -- & \\
\hline Współpraca innowacyjna ze szkołami & & -.27 & & & & & & .26 & & & 29 & \\
\hline wyższymi & .11 & .05 & .03 & & -- & & .10 & .06 & .03 & .13 & .07 & .04 \\
\hline Współpraca innowacyjna z krajowymi & & -.54 & & & & & & .33 & & & & \\
\hline JBR & .10 & .04 & .10 & & -- & & .08 & .12 & .07 & & -- & \\
\hline Współpraca innowacyjna & & -.81 & & & -.36 & & & .40 & & & 56 & \\
\hline z zagranicznymi JBR & .24 & .01 & .03 & .16 & .01 & .03 & .12 & .04 & .01 & .14 & .06 & .02 \\
\hline & & -.21 & & & & & & & & & 37 & \\
\hline praca intiovacy & .07 & .17 & .23 & & -- & & & -- & & .09 & .32 & .20 \\
\hline & & -.29 & & & & & & & & & 45 & \\
\hline Współpraca innowacyjna ogółem & .06 & .36 & .47 & & -- & & & -- & & .08 & .60 & .42 \\
\hline
\end{tabular}

Źródło: opracowanie własne

\section{WNIOSKI}

Wpływ odległości konkurenta, dostawcy i odbiorcy na kształtowanie zachowań innowacyjnych jest zróżnicowany zarówno pod względem kierunku, jak i siły.

Niewielka odległość konkurenta, dostawcy i odbiorcy obniża aktywność innowacyjną, w tym najbardziej jest ograniczana częstotliwość podejmowania współpracy innowacyjnej z instytucjami reprezentującymi świat nauki (krajowe i zagraniczne JBR), a najmniej - skłonność przedsiębiorstw do inwestowania w dotychczas niestosowane środki trwałe, w tym oprogramowanie komputerowe oraz maszyny i urządzenia. Stąd można wnioskować, iż im mniejsza powszechność podejmowania danego działania innowacyjnego, tym większy negatywny wpływ bliskości konkurenta, dostawcy i odbiorcy, przy czym rozpiętość negatywnego wpływu sięga 200\%.

Wpływ obecności konkurenta, dostawcy i odbiorcy w regionie jest najmniej znaczący. Obecność dostawcy i odbiorcy w regionie znacząco przyczynia się do spadku współpracy innowacyjnej z zagranicznymi JBR. Natomiast obecność konkurenta i dostawcy w regionie znacznie ogranicza współpracę innowacyjną ze szkołami wyższymi. 
Przedsiębiorstwa posiadające najbliższych lub głównych konkurentów, dostawców lub odbiorców w kraju częściej podejmują współpracę z krajowymi i zagranicznymi JBR i szkołami wyższymi (konkurent, odbiorca), a w przypadku krajowych dostawców są skłonne do ponoszenia nakładów na działalność B + R. Z uwagi na niskie wartości bezwzględne prawdopodobieństw $(0,03-0,12)$ każdy wzrost współpracy ze światem nauki przyczynia się do podniesienia konkurencyjności badanych przedsiębiorstw.

Pod wpływem konkurentów, dostawców i odbiorców zagranicznych przedsiębiorstwa częściej współpracują ze szkołami wyższymi i z zagranicznymi JBR, przy czym wielkość tego wpływu dochodzi do 75\%.

Analiza wykazała, że dla każdego badanego działania innowacyjnego wartości bezwzględne prawdopodobieństw rosną wraz ze wzrostem odległości. Ponadto kierunek wpływu zawsze dla partnerów lokalnych jest ujemny, a dla partnerów krajowych i zagranicznych dodatni. Potwierdzone zostało założenie, iż obecność lokalnej konkurencji obniża aktywność innowacyjną, ale zjawisko to nie zostało potwierdzone dla lokalnych dostawców i odbiorców. Współpraca z partnerami zagranicznymi sprawia, iż przedsiębiorstwa najczęściej współpracują ze światem nauki w kraju i za granicą.

Przeprowadzone badanie ma liczne ograniczenia, gdyż nie umożliwia dokonania rozgraniczenia pomiędzy bliskością geograficzną, społeczną, organizacyjną, instytucjonalną oraz poznawczą (Boschma, 2005). Z tego też względu bliskość geograficzna nie może być samodzielnym i bezpośrednim wyjaśnieniem badanych zjawisk. Można je wyjaśniać za pomocą innych, nieuwzględnionych w badaniu czynników, takich jak istnienie luki technologicznej i popytowej. Otrzymane wyniki dowodzą, że w badanej grupie przedsiębiorstw najistotniejszym czynnikiem stymulującym aktywność innowacyjną jest popyt generowany przez odbiorców zagranicznych bądź krajowych. Dalszy kierunek analizy powinien dotyczyć powtórzenia przeprowadzonych badań w celu określenia dynamiki zachodzących zmian albo pogłębienia badań o wymienione wcześniej wymiary bliskości międzyorganizacyjnej.

\section{Literatura \\ References}

Ahuja, G. (2000). The duality of collaboration: Inducements and opportunities in the formation of interfirm linkages. Strategic Management Journal, 21(3), 317-343.

Aldrich, J.H., Nelson, F.D. (1984). Linear probability, logit, and probit models, 45. Sage.

Audretsch, B. (1998). Agglomeration and the location of innovative activity. Oxford Review of Economic Policy, 14(2), 18-29.

Bell, G.G. (2005). Clusters, networks, and firm innovativeness. Strategic Management Journal, 26, 287.

Bell, G.G., Zaheer, A. (2007). Geography, networks, and knowledge flow. Organization Science, 18, 955.

Boschma, R. (2005). Proximity and Innovation - a Critical Assessment. Regional Studies, 34(4), 213-229.

Bunnel, T., Coe, N. (2001). Spaces and scales of innovation. Progress in Human Geography, 25(4), 569-589.

Cieślik, A., Michałek, J., Szczygielski, K. (2016). Innovations and Export Performance: Firm-level Evidence from Poland. Entrepreneurial Business and Economics Review, 4(4), 11-28.

Czakon, W. (2012). Sieci w zarządzaniu strategicznym. Warszawa: Oficyna Wolters Kluwer Business. 
Dwojacki, P., Hlousek, J. (2008). Zarzq̨dzanie innowacjami. Gdańsk: Centrum Badawczo-Rozwojowe.

Dzikowski, P. (2016). Wpływ odległości od konkurenta, dostawcy i odbiorcy na aktywność innowacyjną przemysłu średnio-wysokiej i wysokiej techniki w Polsce. Współczesna Gospodarka, 7, 107-117.

Edquist, C., Rees, G.M., Lorenzen, M., Vincent-Lancrin, S. (2001). Cities and regions in the new learning economy. OECD.

Etzkowitz, H., Leydesdorff, L. (2000). The Dynamics of innovation: From national systems and 'Mode 2' to a triple helix of university-industry-government relations. Research Policy, 29, 109-123.

Freel, M.S. (2003). Sectoral patterns of small firm innovation, networking and proximity. Research Policy, 32(5), 751-770.

Gallaud, D., Torre, A. (2005). Geographical proximity and the diffusion of knowledge. W: G. Fuchs, P. Shapira, A. Koch (Eds.). Rethinking Regional Innovation and Change. Path Dependency or Regional Breakthrough? Dordrecht: Springer Verlag, 127-146.

Gertler, M.S. (2003). Tacit knowledge and the economic geography of context, or the undefinable taciness of being (there). Journal of Economic Geography, 3(1), 75-99.

Gilbert, B.A., McDougall, P.P., Audretsch, D.B. (2008). Clusters, knowledge spillovers and new venture performance: An empirical examination. Journal of Business Venturing, 23(4), 405-422.

Gjelsvik, M. (2014). Capabilities for Innovation in a Globalizing World: from Nearly or at a Distance? Entrepreneurial Business and Economics Review, 2(2), 7-20.

Hatzichronoglou, T. (1997). Revision of the high-technology sector and product classification. Sti Working Papers, 2.

Janasz, W., Kozioł-Nadolna, K. (2011). Innowacje w organizacji. Warszawa: PWN.

Kaczmarska-Krawczak, J. (2016). Wdrażanie innowacji w sektorze małych i średnich przedsiębiorstw na przykładzie regionu łódzkiego. Przedsiębiorczość Międzynarodowa, 2(1), 99-108.

Liao, T.F. (1994). Interpreting probability models: Logit, probit, and other generalized linear models, 101. Sage.

Majewska, J., Truskolaski, S. (2017). Spatial concentration of economic activity and competitiveness of Central European regions. Przedsiębiorczość Międzynarodowa, 3(1), 47-64.

Malerba, F. (2004). Sectoral Systems of Innovation. Cambridge: Cambridge University Press.

$\mathrm{Mu}$ J., Peng, G., Love, E. (2008). Interfirm networks, social capital, and knowledge flow. Journal of Knowledge Management, 12(4), 86-100.

OECD (2008). Podręcznik Oslo: Zasady gromadzenia i interpretacji danych dotyczących innowacji. Warszawa.

Powell, W., Koput, K., Smith-Doerr, L. (1996). Interorganizational Collaboration and the Locus of Innovation: Networks of Learning in Biotechnology. Administrative Science Quarterly, 41(1), 116-145.

Rees, G., Lorenz, M., Vincent-Lancrin, S. (2001). OECD: Cities and Regions in the Learning Economy. Center for Educational Research and Innovation (CERI).

Rocznik statystyczny przemysłu (2014). Warszawa: GUS, 437.

Rogut, A. (2007). Modele sektorowego systemu innowacji. Raport ze studiów literaturowych. Łódź: Społeczna Wyższa Szkoła Przedsiębiorczości i Zarządzania w Łodzi, 7.

Saxenian, A. (1994). Lessons from silicon valley. Technology Review-Manchester NH-, 97, 42.

Stańczyk-Hugiet, E., Sus, A. (2012). Konsekwencje przynależności do sieci. W: J. Niemczyk, E. Stańczyk-Hugiet, B. Jasiński (red.) (2012). Sieci międzyorganizacyjne. Współczesne wyzwanie dla teorii i praktyki zarządzania. Warszawa: Wydawnictwo C.H. Beck, 87.

Storper, M. (1995), The resurgence of regional economics, ten years later: the region as a nexus of untraded interdependencies. European Urban and Regional Studies, 2(3), 191-221.

Świadek, A., Szopik-Depczyńska, K. (2011). Dostawcy w łańcuchu dostaw w kształtowaniu innowacyjności polskich regionów. Zeszyty Naukowe Szkoły Głównej Handlowej. Kolegium Gospodarki Światowej, 31.

Wach, K. (2016). Innovative Behaviour of High-Tech Internationalized Firms: Survey Results from Poland. Entrepreneurial Business and Economics Review, 4(3), 153-165.

Zaheer, A., Bell, G.G. (2005). Benefiting from Network position: firm capabilities, structural holes, and performance. Strategic Management Journal, 26(9), 809-825. 
Piotr Dzikowski, dr inż., adiunkt, Uniwersytet Zielonogórski, Zakład Innowacji i Przedsiębiorczości. Zainteresowania badawcze dotyczą determinant innowacji i przedsiębiorczości w systemach przemysłowych, w tym determinant aktywności innowacyjnej w sieciach o różnym poziomie techniki.

Piotr Dzikowski, Ph.D., University of Zielona Gora, Division of Innovation and Entrepreneurship. His research interest focuses on drivers of innovation and entrepreneurship in industry systems, including drivers of innovation activity in industry networks with different levels of technology.

\section{Adres/address:}

Uniwersytet Zielonogórski

Zakład Innowacji i Przedsiębiorczości

ul. Podgórna 50, 65-246 Zielona Góra, Polska

e-mail: p.dzikowski@wez.uz.zgora.pl 